\title{
Familial Hypertrophic Cardiomyopathy Type 4
}

National Cancer Institute

\section{Source}

National Cancer Institute. Familial Hypertrophic Cardiomyopathy Type 4. NCI Thesaurus.

Code C133725.

An autosomal dominant condition caused by mutation(s) in the MYBPC3 gene, encoding MYBPC3 protein. It is characterized by severe neonatal hypertrophic cardiomyopathy. 